\title{
Transmission of the Bean-Associated Cytorhabdovirus by the Whitefly Bemisia tabaci MEAM1
}

\author{
Bruna Pinheiro-Lima ${ }^{1,2,3}$, Rita C. Pereira-Carvalho ${ }^{2}$, Dione M. T. Alves-Freitas ${ }^{1}(\mathbb{0}$, \\ Elliot W. Kitajima ${ }^{4}$, Andreza H. Vidal ${ }^{1,3}$, Cristiano Lacorte ${ }^{1}$, Marcio T. Godinho ${ }^{1}$, \\ Rafaela S. Fontenele ${ }^{5}$, Josias C. Faria ${ }^{6}$ (D), Emanuel F. M. Abreu ${ }^{1}$, Arvind Varsani ${ }^{5,7}$, \\ Simone G. Ribeiro ${ }^{1, *(D)}$ and Fernando L. Melo ${ }^{2,3, *(\mathbb{D})}$ \\ 1 Embrapa Recursos Genéticos e Biotecnologia, Brasília DF 70770-017, Brazil; \\ pinheiro.limab@gmail.com (B.P.-L.); dionebio@gmail.com (D.M.T.A.-F.); andrezactg@hotmail.com (A.H.V.); \\ cristiano.lacorte@embrapa.br (C.L.); marcioslash@gmail.com (M.T.G.); \\ emanuel.abreu@embrapa.br (E.F.M.A.) \\ 2 Departamento de Fitopatologia, Instituto de Biologia, Universidade de Brasília, Brasília DF 70275-970, Brazil; \\ rcpcarvalho@unb.br \\ 3 Departamento de Biologia Celular, Instituto de Biologia, Universidade de Brasília, \\ Brasília DF 70275-970, Brazil \\ 4 Departamento de Fitopatologia, Escola Superior de Agricultura Luiz de Queiroz, Piracicaba SP 13418-900, \\ Brazil; ewkitaji@usp.br \\ 5 The Biodesign Center for Fundamental and Applied Microbiomics, Center for Evolution and Medicine \\ School of Life Sciences, Arizona State University, Tempe, AZ 85287-5001, USA; \\ rafasfontenele@gmail.com (R.S.F.); avarsani@gmail.com (A.V.) \\ 6 Embrapa Arroz e Feijão, Goiânia GO 75375-000, Brazil; josias.faria@embrapa.br \\ 7 Structural Biology Research Unit, Department of Integrative Biomedical Sciences, University of Cape Town, \\ Observatory, Cape Town 7701, South Africa \\ * Correspondence: simone.ribeiro@embrapa.br (S.G.R.); flucasmelo@gmail.com (F.L.M.)
}

Received: 4 August 2020; Accepted: 11 September 2020; Published: 15 September 2020

check for updates

\begin{abstract}
The knowledge of genomic data of new plant viruses is increasing exponentially; however, some aspects of their biology, such as vectors and host range, remain mostly unknown. This information is crucial for the understanding of virus-plant interactions, control strategies, and mechanisms to prevent outbreaks. Typically, rhabdoviruses infect monocot and dicot plants and are vectored in nature by hemipteran sap-sucking insects, including aphids, leafhoppers, and planthoppers. However, several strains of a potentially whitefly-transmitted virus, papaya cytorhabdovirus, were recently described: (i) bean-associated cytorhabdovirus (BaCV) in Brazil, (ii) papaya virus $\mathrm{E}$ (PpVE) in Ecuador, and (iii) citrus-associated rhabdovirus (CiaRV) in China. Here, we examine the potential of the Bemisia tabaci Middle East-Asia Minor 1 (MEAM1) to transmit BaCV, its morphological and cytopathological characteristics, and assess the incidence of $\mathrm{BaCV}$ across bean producing areas in Brazil. Our results show that $\mathrm{BaCV}$ is efficiently transmitted, in experimental conditions, by B. tabaci MEAM1 to bean cultivars, and with lower efficiency to cowpea and soybean. Moreover, we detected BaCV RNA in viruliferous whiteflies but we were unable to visualize viral particles or viroplasm in the whitefly tissues. $\mathrm{BaCV}$ could not be singly isolated for pathogenicity tests, identification of the induced symptoms, and the transmission assay. $\mathrm{BaCV}$ was detected in five out of the seven states in Brazil included in our study, suggesting that it is widely distributed throughout bean producing areas in the country. This is the first report of a whitefly-transmitted rhabdovirus.
\end{abstract}

Keywords: common bean; Phaseolus vulgaris; cytorhabdovirus; whitefly; Bemisia tabaci; vector; virus transmission; virus evolution 


\section{Introduction}

Rhabdoviruses (family Rhabdoviridae) are a group of negative-sense, single-stranded RNA viruses that infect plants, vertebrate animals, and invertebrate animals. They cause harmful diseases in humans and animals and can cause high yield losses in crops. Plant-infecting rhabdoviruses are currently taxonomically assigned to six genera [1]. Members of the Dichorhavirus genus have a bi-segmented genome, infect di- and monocotyledonous plants, and are transmitted by Brevipalpus mites. Viruses belonging to the Varicosavirus genus also have a bi-segmented genome, infect plants of the Compositae and Solanaceae families, and are transmitted by zoospores of the fungus Olpidium brassicae. Non-segmented plant rhabdoviruses infect mono- and dicot plants and are vectored in nature by hemipteran sap-sucking insects, including aphids, leafhoppers, and planthoppers [2]. Moreover, there is a close relationship between plant rhabdoviruses and their vectors, and each virus may be vectored by one species or a few closely related ones [3]. Viruses that replicate within the nuclei of infected plant cells are assigned to the genera Alphanucleorhabdovirus, Betanucleorhabdovirus, and Gammanucleorhabdovirus, while those that multiply in the cell cytoplasm belong to the Cytorhabdovirus [2,4]. Insect and mite-transmitted rhabdoviruses also replicate in their arthropod vectors and are transmitted in a persistent propagative manner [3,5]. However, no information on vectors and transmission characteristics is available for most of these viruses [5].

Bean-associated cytorhabdovirus (BaCV) was identified in transgenic bean golden mosaic virus (BGMV)-resistant common bean lines [6]. The BaCV genome has a $3^{\prime}-\mathrm{N}-\mathrm{P}-\mathrm{M}-\mathrm{G}-\mathrm{L}-5^{\prime}$ [nucleocapsidprotein $(\mathrm{N})$, phosphoprotein $(\mathrm{P})$, matrix protein $(\mathrm{M})$, glycoprotein $(\mathrm{G})$, and RNA-dependent RNA polymerase (RdRp) protein (L)] organization that is typical of rhabdoviruses and between $\mathrm{P}$ and $\mathrm{M}$, the BaCV genome encodes two accessory genes, $\mathrm{P} 3$ and P4 [6]. A closely related virus with a genome sequence identity of $97 \%$ named papaya virus $\mathrm{E}$ (PpVE) has been reported from papaya plants in Ecuador [7]. Based on the high sequence identity between the two virus sequences, it was proposed that the virus species would be named Papaya cytorhabdovirus with strains PpVE infecting papayas and $\mathrm{BaCV}$ infecting beans $[8,9]$.

To characterize the bean-infecting cytorhabdovirus strain in detail, we carried out the molecular cloning and defined its morphological and cytopathological characteristics. Moreover, we observed a high prevalence of $\mathrm{BaCV}$ in bean fields in Brazil and determined the efficient transmission of $\mathrm{BaCV}$ by the whitefly Bemisia tabaci Middle East-Asia Minor 1 (MEAM1), a hitherto unknown feature for a plant rhabdovirus.

\section{Materials and Methods}

\subsection{Plant Material}

Fifteen common bean plants (cultivar 'Pérola') with typical virus symptoms of mosaic, leaf distortion, crumpling, and dwarfing (Figure 1) were collected in a commercial field in Luziânia, Goiás State, in June 2016. Leaf samples from the 15 plants were detached and stored at $-80{ }^{\circ} \mathrm{C}$. Six plants were transplanted to soil-filled pots and maintained in a screen-protected cage, without removing the abundant whitefly colonies present in the plant leaves. One of the transplanted plants survived and was used for virus transmission and cloning of the genome of BaCV-Luz. 

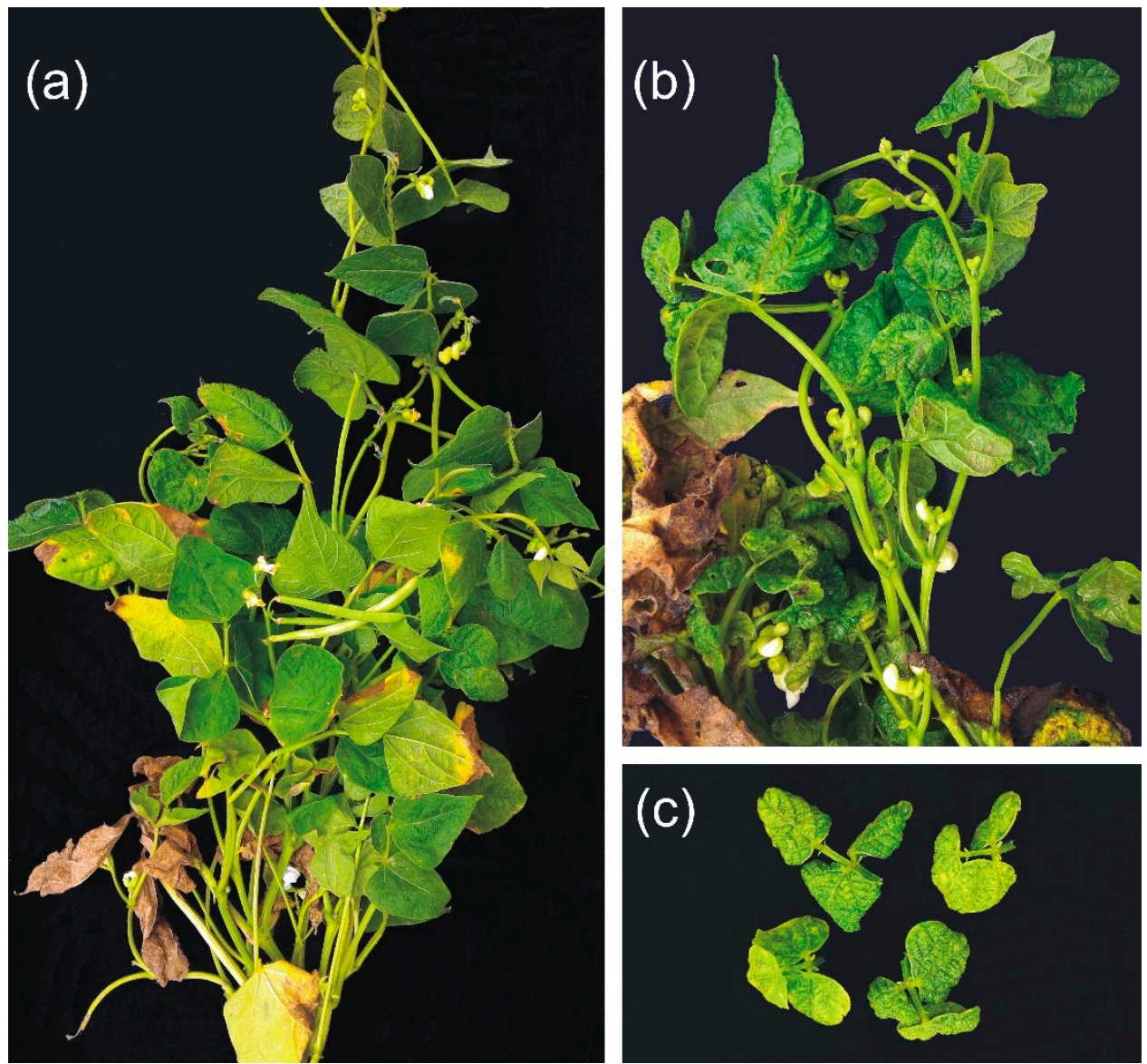

Figure 1. Symptoms in common bean plants collected in a commercial field in Luziânia, Goiás state with mixed infection by bean-associated cytorhabdovirus (BaCV), cowpea mild mottle virus (CPMMV), and bean golden mosaic virus (BGMV) and whitefly colonization. (a) Mosaic and leaf wrinkling. (b) Mosaic, severe leaf distortion, and deformation. (c) Detail of leaves with reduced area, yellow mosaic, and severe crinkling and curling.

\subsection{Distribution of BaCV in Common Beans in Brazil}

Initially, the 15 plants collected in Luziânia were examined by RT-PCR or PCR for the presence of bean-infecting viruses frequently found in Brazil, the whitefly-transmitted CPMMV (family Betaflexiviridae; genus Carlavirus), BGMV, and macroptilium yellow spot virus-MaYSV (family Geminiviridae; genus Begomovirus), the chrysomelid beetle-transmitted bean rugose mosaic virus-BRMV (family Secoviridae; genus Comovirus), and the recently identified cytorhabdovirus BaCV. To determine the occurrence of BaCV in different areas in Brazil (Figure 2), additional bean samples were collected from experimental or commercial bean fields between 2016 to 2018, including Brasília $(n=30)$, Distrito Federal-DF; Santo Antônio de Goiás $(n=26)$, Luziânia $(n=15)$, Cristalina $(n=43)$, Urutai $(n=1)$, and Araçu $(n=1)$ in Goiás State-GO; Sorriso, Mato Grosso State-MT $(n=2)$; Bonfinópolis de Minas $(n=3)$, Paracatu $(n=1)$, Três Pontas $(n=5)$ in Minas Gerais State; and Arapiraca $(n=5)$ in Alagoas State. In addition, we analyzed bean samples from our archived collection. Plants collected in Brasília, DF in $2007(n=2)$, PAD/DF Paranoá, DF in $2012(n=11)$, and Riacho Fundo, DF in $2015(n=41)$; Cruz das Almas $(n=8)$, Morro do Chapéu $(n=4)$, Piritiba $(n=3)$, and Antônio Gonçalves $(n=2)$ in Bahia State in 2015; and Palmital $(n=1)$ in São Paulo State in 2015 were screened for BaCV infection. In total, 219 bean plants were screened for the presence of BaCV, CPMMV, and BGMV (41 BGMV-immune cultivar 'BRS FC 401 RMD' plants were not tested for BGMV). 


\section{Bean sampling locations}

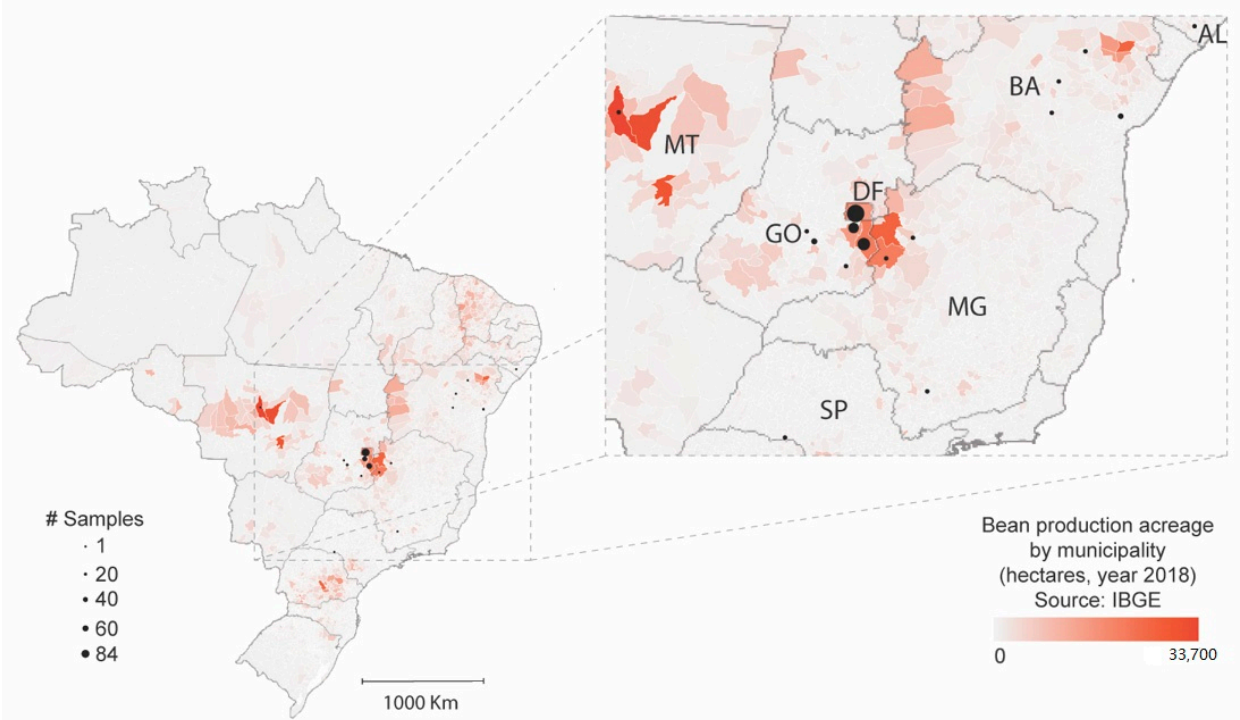

Figure 2. Summary of the distribution of the bean sampling locations at Alagoas (AL), Bahia (BA), Goiás (GO), Minas Gerais (MG), Mato Grosso (MT), São Paulo (SP) states and Distrito Federal (DF). Each municipality was colored in red according to the bean planted area (in hectare), obtained from the Brazilian Institute of Geography (https:/www.ibge.gov.br/) [10]. The black circles represent the sample sites, and their size is proportional to the number of collected plants. The samples were collected between 2007 and 2018.

\subsection{RNA and DNA Extraction}

Total RNA was extracted from $100 \mathrm{mg}$ of plant leaf tissue (pulverized in liquid nitrogen) using the TRIzol Reagent (Invitrogen, Carlsbad, CA, USA) according to the manufacturer's instructions. Total RNA was also extracted from (i) a group of 30 whitefly individuals, (ii) from one single individual, and (iii) parts of one single whitefly (head/thorax or abdomen). One fourth and one-tenth of the reagent's volumes of the standard TRIzol Reagent protocol were used for 30 whiteflies and one or parts of an insect, respectively. Total DNA was extracted from leaves and whiteflies using the CTAB protocol [11].

\subsection{RT-PCR, PCR, and Cloning}

The sequences and characteristics of all primers used in this study are summarized in Table S1. To determine the complete genome sequence of BaCV-Luz, first we determined the $5^{\prime}$ and $3^{\prime}$ ends by rapid amplification of cDNA ends (RACE) as previously described [6,12,13]. Next, based on the genome sequence of BaCV-GO [6] and BaCV-Luz leader and trailer sequences, primers were designed to amplify the virus genome by RT-PCR in six fragments overlapping in at least $150 \mathrm{nt}$. The cDNA was synthesized with $5 \mu \mathrm{L}$ of total RNA (approximately $1 \mu \mathrm{g}$ ) using SuperScript III Reverse Transcriptase (Invitrogen, Carlsbad, CA, USA), Anchored Oligo(dT)20 (Invitrogen, Carlsbad, CA, USA) and random primers [14]. One microliter of cDNA was used in PCR reactions with LongAmp Taq DNA Polymerase (New England Biolabs, Ipswich, MA, USA) and specific primers for each fragment (Table S1). Amplicons were gel-purified, cloned into PCR 2.1 TOPO TA vector (Invitrogen, Carlsbad, CA, USA) and sequenced. At least two clones of each fragment were sequenced at Macrogen Inc. (Seoul, Korea).

Detection of BaCV (in plants and whiteflies), CPMMV (in plants and whiteflies), and BRMV (in plants) was carried out by RT-PCR using the cDNA prepared as described above as template. PCR reactions were performed with Taq DNA Polymerase (Invitrogen, Carlsbad, CA, USA) using $1 \mu \mathrm{L}$ of cDNA and primers BaCV_1F/BaCV_1579R, CPMMV_4000F/CPMMV_4500R [15], 
and BRMV1_76F/BRMV1_521R [6] specific for BaCV, CPMMV, and BRMV, respectively. For BGMV and MaYSV PCR-based infection surveys of field samples, total extracted plant DNA was used as template and primers BGMV_HPXHO/BGMV_HPKPN for BGMV [16] and MaYSV-249F/MaYSV-1083R for MaYSV. A portion of the PCR amplicons was verified by cloning in PCR 2.1 TOPO TA vector (Invitrogen, Carlsbad, CA, USA) and Sanger sequencing.

Whiteflies populations from the field, as well as from the Universidade de Brasília rearing facility, were identified as B. tabaci MEAM1 by genotyping the insects using PCR-RFLP as described by Bosco, et al. [17]. Amplification of a region of the mitochondrial cytochrome oxidase I gene (mtCOI) was undertaken by PCR using whitefly total DNA as template and the primers COI-Fw/COI-Rv [17] (Table S1). The amplicons were digested with Taq I endonuclease (New England Biolabs, Ipswich, MA, USA). The digestion products were resolved in a 1.2\% agarose gel electrophoresis, and the profile of the bands was compared with the profiles for B. tabaci MEAM1 (synonym biotype B) and B. tabaci MED (synonym biotype Q) [17].

\subsection{Sequence Analysis}

All sequences generated in this study were trimmed and assembled using Geneious software (v. 11, Biomatters, Auckland, New Zealand) [18]. The sequence identity was confirmed by BLASTn analysis [19]. The complete genome of BaCV-Luz isolate was deposited in GenBank under the accession number MT811775. The RdRp amino acid sequence of BaCV-Luz was aligned with those of all cytorhabdoviruses available in GenBank (as by May 2020) (Table S2) using MAFFT algorithm [20] implemented in Geneious. Maximum likelihood (ML) phylogenetic tree was inferred using IQ-TREE [21], with node support estimated with the Shimodaira-Hasegawa approximate likelihood ratio test (SH-aLRT) [22]. Moreover, the amino acid sequences of the glycoproteins encoded by the cytorhabdoviruses were used to generate a sequence similarity network using the Enzyme Function Initiative-Enzyme Similarity Tool (EFI-EST) [23] with an alignment score threshold of 35 and minimum E-value threshold of $1 \times 10^{-5}$. The network was visualized in Cytoscape v3.7.1 [24]. Pairwise sequence identity comparisons were performed using the Sequence Demarcation Tool (SDT) v.1.2 [25].

\subsection{BaCV Transmission by B. tabaci MEAM1}

After confirming the infection by BaCV, CPMMV, and BGMV, a bean plant colonized by whiteflies transplanted from the field was used as an inoculum source for transmission tests (Figure 3). Initially, eight young bean seedlings each of cultivars 'Pérola', 'Jalo', and 'BRS FC 401 RMD' were placed in the cage with the whitefly-infested plant. Seven days later, another set of eight seedlings of each cultivar was placed inside the same cage. Plant samples were collected 14 days after their introduction into the cage and tested for the presence of BaCV, CPMMV, and BGMV. Since 'BRS FC 401 RMD' plants are immune to BGMV [26], they were not tested for BGMV infection. Whiteflies were also collected and tested for the presence of BaCV. Following this, the BaCV-Luz isolate was maintained in 'BRS FC 401 RMD' plants by introducing plantlets every three to four weeks in the cage, and when the population of whiteflies was declining, adult individuals from the rearing facility from the Universidade de Brasilia were added to the cage for BaCV-Luz isolate maintenance until 2018. 
Whitefly-mediated BaCV transmission assay

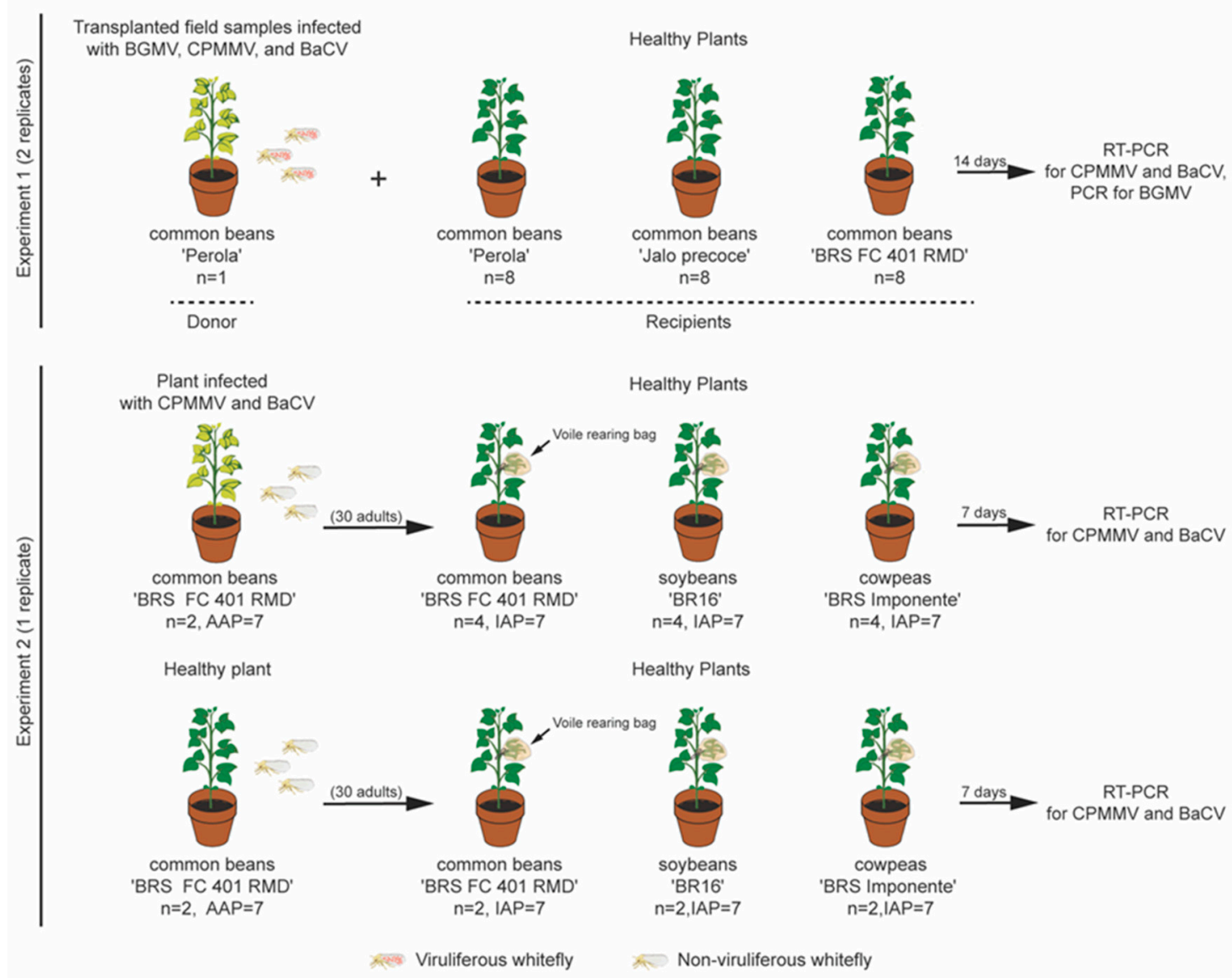

Figure 3. Whitefly (Bemisia tabaci Middle East-Asia Minor 1 (MEAM1)) mediated transmission of BaCV. Outline of experimental procedures: In experiment 1, a common bean plant with whitefly colonies from the field was used as an inoculum source for BaCV (BGMV and CPMMV) transmission to bean plants 'Jalo', 'Pérola' and 'BRS FC 401 RMD'. After 14 days, samples were collected, and BaCV (CPMMV and BGMV) transmission confirmed by RT-PCR and PCR. In experiment 2, whiteflies were exposed to BaCV(and CPMMV)-infected plants for a 7-days acquisition period. Thirty whiteflies were transferred from the inoculum source plant to a healthy plant leaf wrapped by a voile rearing bag for a 7-days inoculation period. After seven days, samples were collected and tested by RT-PCR. The same procedure was applied to healthy plants with aviruliferous whiteflies as controls.

To further refine the transmission tests, two three-week old 'BRS FC 401 RMD' plants infected with BaCV-Luz (and CPMMV) were removed from the cage, sprayed with imidacloprid ( $32 \mathrm{mg} / \mathrm{L}$ ) to eliminate any whiteflies present in the plants, transferred to a bugdorm tent, and kept in a greenhouse at room temperature for 10 days. B. tabaci MEAM1 individuals were reared in cabbage plants (Brassica oleraceae var. capitata L.) at the Biological Experimental Station of the Universidade de Brasília. To synchronize the whiteflies' age, adult flies were removed from the cabbage plants, the plants were placed in a bugdorm cage, and kept in a greenhouse for three days. One-to-three-day old adult whiteflies were collected from the cabbage plants and transferred to the BaCV-Luz-infected bean plants for an acquisition accession period (AAP) of 7 days (Figure 3). As a control, a batch of whiteflies was placed for 7 days in healthy bean plants. Next, 25 to 30 potentially viruliferous whiteflies were transferred from the virus-infected source plants to a polyester voile rearing bag previously placed around a trifoliate leaf of 4 healthy beans 'BRS FC 401 RMD', 4 healthy soybeans [Glycine max (L.) Merr. 'BR16'], and 4 healthy cowpeas [Vigna unguiculata (L.) Walp. 'BRS Imponente'] plants for an inoculation access period (IAP) of 7 days. Likewise, as controls, non-viruliferous flies were placed 
in 2 healthy plants of each plant species for 7 days. After this period, the leaves inside the polyester voile bags were detached from plants to avoid nymphal maturation, and plants were sprayed with imidacloprid (32 mg/L) to remove any possible remaining whiteflies [27]. Plants were observed for the development of symptoms, and virus infection was confirmed by RT-PCR, as described above.

\subsection{BaCV Detection in Plants and Whiteflies}

To identify the presence of BaCV-Luz in bean plants and whiteflies, the total RNA was treated with TURBO DNase (Invitrogen, Carlsbad, CA, USA) to eliminate any DNA trace from the RNA preparation as described by Cao, et al. [28]. The cDNA was prepared with Anchored Oligo (dT) 20 primer (Invitrogen, Carlsbad, CA, USA) and SuperScript III Reverse Transcriptase (Invitrogen, Carlsbad, CA, USA) and the PCR reactions were performed with primers specific for all BaCV genes (Table S1). The transcripts for Actin-11 (act11) [29] and the small Rubisco subunit (RbcS) [30] genes from common bean, and Ribosomal protein L9 (RpL9) [31] and Vacuolar ATPase (v-ATPase) subunit A [31] genes from whitefly, were used as internal reference controls and to identify possible transcripts ingested by the whiteflies during the feeding in the bean plants (Table S1).

\subsection{Transmission Electron Microscopy}

Small leaf pieces were cut from 'BRS FC 401 RMD' bean plants that were experimentally inoculated with whitefly and tested positive for BaCV by RT-PCR. Leaf sections were fixed overnight with Karnovsky modified fixative (2.5\% glutaraldehyde and $2 \%$ paraformaldehyde in $0.05 \mathrm{M}$ cacodylate buffer, $\mathrm{pH}$ 7.2). The samples were post-fixed with $1 \%$ osmium tetroxide (in $0.05 \mathrm{M}$ cacodylate buffer) for 1-2 h. Tissues were dehydrated, embedded in low viscosity epoxy Spurr resin (Electron Microscopy Sciences, Hatfield, PA, USA), and sectioned in a Leica UC6 ultramicrotome equipped with a Diatome diamond knife. Ultrathin sections (70-100 nm thick) were transferred onto 300 mesh copper grids, stained with 3\% uranyl acetate and Reynold's lead citrate, and examined in a JEOL JEM 1011 transmission electron microscope. Healthy bean leaves were used as controls. Images were digitally recorded. Whiteflies were reared and collected from BaCV-Luz-infected bean plants, dipped into a $\mathrm{NaCl}$ 0.9\% solution, and dissected at the thorax region in two parts: head/thorax and abdomen. For each whitefly, either the head/thorax or the abdomen parts were used for BaCV detection by RT-PCR, and the other part was fixed in a cold solution of $2.5 \%$ glutaraldehyde and $1.8 \%$ sucrose in $0.1 \mathrm{M}$ cacodylate buffer. For the whiteflies that one part of the body was positive for BaCV presence by RT-PCR, the other part was processed to be examined by electron microscopy, as described above for plant tissues. Three pairs of head and abdominal parts of presumably viruliferous whiteflies were examined.

\section{Results and Discussion}

\subsection{BaCV Is Widely Distributed throughout Common Bean Producing Areas in Brazil}

$\mathrm{BaCV}$ was identified for the first time in Brazil in 2014 in bean plants collected in Santo Antônio de Goiás, Goiás State (GO) [32]. In June 2016, severe virus-like symptoms were recorded by farmers in Luziânia (GO) (Figure 1). The incidence of these symptoms in the bean plants ranged from $20 \%$ to $80 \%$, depending on the area. The bean fields were heavily infested by whiteflies migrating from nearby cotton and tomato fields. Therefore, the first 15 bean plants received from the farmers were screened by PCR or RT-PCR for the presence of the whitefly-borne viruses BGMV, MaYSV, and CPMMV in addition to BRMV, and the new cytorhabdovirus BaCV (Figure S1). None of the plants were infected with MaYSV or BRMV. Conversely, all 15 plants had a mixed infection with BaCV, BGMV, and CPMMV.

Given the high infection rate, we further investigated the occurrence of these viruses in newly collected (2016-2018) and archived samples (2007-2016) from Central, Southeast, and Northeastern Brazil, comprising six states and the federal district (Figure 2). In total, 219 plants were analyzed, and $91(41.55 \%)$ were infected by BaCV (Table 1 and Figure 4$)$. Most of the plants analyzed (46.12\%) 
were sampled in Goiás, Central Brazil, one of the top bean-producing States in the country, where the incidence of $\mathrm{BaCV}$ reached up to $100 \%$, depending on the area (Table 1). Despite the uneven sampling among regions, we were able to detect $\mathrm{BaCV}$ in Southeast and Northeast regions, which are more than $2000 \mathrm{~km}$ apart, suggesting that BaCV is widely distributed throughout bean producing areas in the country. However, to have a better view of the prevalence of $\mathrm{BaCV}$ in the bean crops in Brazil, further sampling should be conducted in additional bean cultivating areas in the Southeastern, Northeastern, and Southern states.

Table 1. Detection of BaCV, CPMMV, and BGMV in common bean samples collected in Brazil by RT-PCR and PCR.

\begin{tabular}{|c|c|c|c|c|c|c|}
\hline \multirow[t]{2}{*}{ State/Total Number of Samples } & \multirow[t]{2}{*}{ City } & \multirow[t]{2}{*}{$\begin{array}{c}\text { Sampled } \\
\text { Areas }\end{array}$} & \multirow[t]{2}{*}{ Year } & \multicolumn{3}{|c|}{$\begin{array}{l}\text { Virus Incidence } \\
\text { (Infected/Tested) }\end{array}$} \\
\hline & & & & $\mathrm{BaCV}$ & CPMMV & BGMV \\
\hline \multirow[t]{4}{*}{ Bahia (BA) $(n=17)$} & Cruz das Almas & 1 & 2015 & $2 / 8$ & $8 / 8$ & $4 / 8$ \\
\hline & Morro do Chapéu & 1 & 2015 & $0 / 4$ & $3 / 4$ & $0 / 4$ \\
\hline & Piritiba & 1 & 2015 & $0 / 3$ & $3 / 3$ & $0 / 3$ \\
\hline & Antônio Gonçalves & 1 & 2015 & $0 / 2$ & $2 / 2$ & $0 / 2$ \\
\hline Total in Bahia & & & & $2 / 17$ & $16 / 17$ & $4 / 17$ \\
\hline Alagoas $(\mathrm{AL})(\mathrm{n}=5)$ & Arapiraca & 1 & 2018 & $0 / 5$ & $4 / 5$ & $1 / 5$ \\
\hline Total in Alagoas & & & & $0 / 5$ & $4 / 5$ & $1 / 5$ \\
\hline \multirow[t]{3}{*}{ Minas Gerais $(M G)(n=9)$} & Bonfinópolis de Minas & 1 & 2016 & $0 / 3$ & $3 / 3$ & $0 / 3$ \\
\hline & Paracatu & 1 & 2016 & $1 / 1$ & $1 / 1$ & $1 / 1$ \\
\hline & Três Pontas & 1 & 2018 & $0 / 5$ & $1 / 5$ & $2 / 5$ \\
\hline Total in Minas Gerais & & & & $1 / 9$ & $5 / 9$ & $3 / 9$ \\
\hline São Paulo (SP) $(\mathrm{n}=1)$ & Palmital & 1 & 2015 & $1 / 1$ & $1 / 1$ & $1 / 1$ \\
\hline Total in São Paulo & & & & $1 / 1$ & $1 / 1$ & $1 / 1$ \\
\hline \multirow[t]{13}{*}{ Goiás (GO) (n = 101) } & Luziânia & 1 & 2016 & $15 / 15$ & $15 / 15$ & $15 / 15$ \\
\hline & & 2 & 2016 & $7 / 7$ & $7 / 7$ & $7 / 7$ \\
\hline & & 3 & 2016 & $3 / 4$ & $4 / 4$ & $4 / 4$ \\
\hline & & 4 & 2016 & $4 / 4$ & $4 / 4$ & $4 / 4$ \\
\hline & Cristalina & 1 & 2016 & $10 / 14$ & $14 / 14$ & $14 / 14$ \\
\hline & & 2 & 2016 & $0 / 14$ & $12 / 14$ & $13 / 14$ \\
\hline & & 3 & 2016 & $11 / 11$ & $10 / 11$ & $11 / 11$ \\
\hline & & 4 & 2016 & $4 / 4$ & $4 / 4$ & $4 / 4$ \\
\hline & Santo Antônio de Goiás & 1 & 2016 & $0 / 4$ & $4 / 4$ & $4 / 4$ \\
\hline & & 2 & 2016 & $2 / 17$ & $17 / 17$ & $8 / 8$ \\
\hline & & 1 & 2018 & $0 / 5$ & $4 / 5$ & $4 / 5$ \\
\hline & Urutaí & 1 & 2018 & $0 / 1$ & $0 / 1$ & $0 / 1$ \\
\hline & Araçu & 1 & 2018 & $0 / 1$ & $1 / 1$ & $1 / 1$ \\
\hline Total in Goiás & & & & $56 / 101$ & $96 / 101$ & $89 / 92$ \\
\hline \multirow[t]{5}{*}{ Distrito Federal (DF) $(\mathrm{n}=84)$} & Brasília & 1 & 2017 & $8 / 30$ & $19 / 30$ & $14 / 30$ \\
\hline & & 1 & 2007 & $0 / 2$ & $0 / 2$ & $2 / 2$ \\
\hline & & 1 & 2012 & $0 / 11$ & $1 / 11$ & $7 / 11$ \\
\hline & & 1 & 2015 & $8 / 12$ & $6 / 12$ & - \\
\hline & & 2 & 2015 & $15 / 29$ & $25 / 29$ & - \\
\hline Total in Distrito Federal & & & & $31 / 84$ & $51 / 84$ & $23 / 43$ \\
\hline Mato Grosso (MT) $(\mathrm{n}=2)$ & Sorriso & 1 & 2018 & $0 / 2$ & $1 / 2$ & $2 / 2$ \\
\hline Total in Mato Grosso & & & & $0 / 2$ & $1 / 2$ & $2 / 2$ \\
\hline TOTAL & & & & $91 / 219$ & $174 / 219$ & $123 / 169$ \\
\hline
\end{tabular}


Mixed viral infection in common bean plants

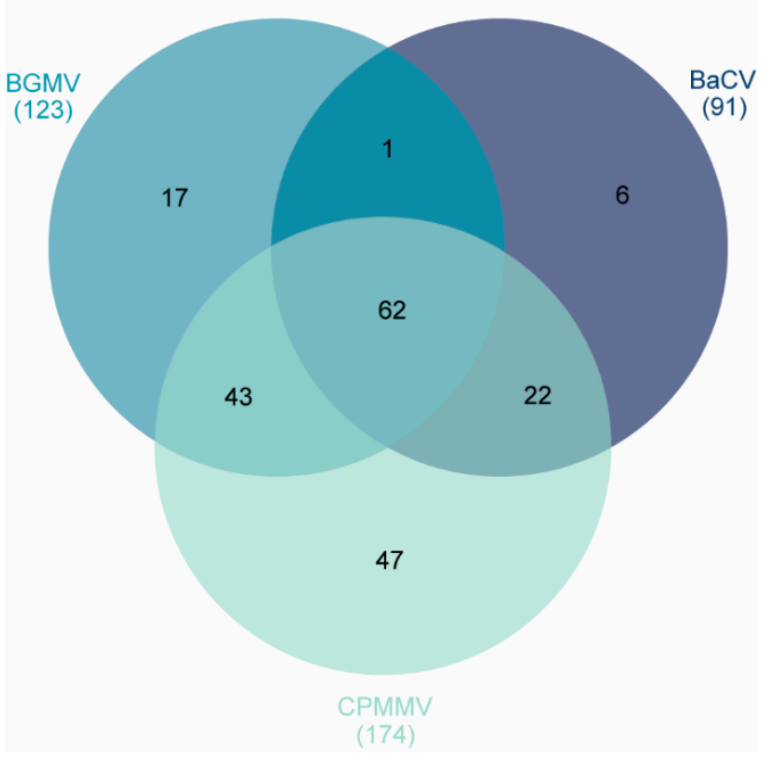

Figure 4. Distribution of viral infections in 219 common bean plants from 2007 to 2018 . BaCV was found mostly in mixed infections with BGMV and CPMMV. Only six plants were found singly infected with $\mathrm{BaCV}$.

$\mathrm{BaCV}$ was found in a single infection only in six samples of BGMV-resistant 'BRS FC401 RMD' plants collected in Riacho Fundo, DF, in 2015. The remaining $85 \mathrm{BaCV}$ positive plants were co-infected with CPMMV $(n=22)$, BGMV $(n=1)$ or with CPMMV and BGMV $(n=62)$ (Table 1 , Figure 4$)$. Mixed infections were, therefore, common in these plants. Viral co-infections are very common and, in the field, seem to be the rule rather than the exception, and may result in synergistic effects and stronger symptoms [33]. Moreover, the change in the plant phenotype induced by the co-infection can alter or increase the attraction of vectors and facilitate the transmission of these viruses and enhance epidemics [34]. Unfortunately, singly BaCV-infected samples were identified only in archived samples, and we do not have records of the specific symptoms displayed by these plants. Therefore, it was impossible to establish possible effects of mixed infections on the severe symptoms observed in the field. Importantly, the phenotype of plants in the field is also influenced by other biotic and abiotic factors such as water and temperature stress and infection by other pathogens like bacteria and fungi.

\subsection{Evolutionary Analysis Indicates Whiteflies as the Potential Vector for $\mathrm{BaCV}$}

The complete BaCV-Luz genome was determined by PCR of six overlapping fragments and was 13,467 nt in length. As expected, the genome presented the seven ORFs originally described in BaCV-GO (N, P, P3, P4, M, G, and L), flanked by two non-transcribed leader and trailer regions (Figure 5). As shown in Table S3, the complete genome of BaCV-Luz shares $99.8 \%$ and $96.3 \%$ identity with BaCV-GO and PpVE, respectively. To further investigate the phylogenetic relationship of cytorhabdoviruses, we aligned $28 \mathrm{RdRP}$ amino acid sequences (2374 aa in length, including gaps) from reference cytorhabdoviruses available in Genbank, including two sequences derived from transcriptomes of B. tabaci (Table S2). The phylogenetic analysis shows that cytorhabdoviruses cluster in monophyletic groups according to its potential vector: aphid [35-39], planthopper [40-45], leafhopper [46], whitefly, and an undescribed vector (Figure 6). As previously suggested [7,47,48], $\mathrm{BaCV}$ isolates and PpVE were closely related to B. tabaci TSA 2 (AKC57270.1), confirming that these viruses belong to the species Papaya cytorhabdovirus. Moreover, yerba mate chlorosis-associated virus clustered with B. tabaci TSA 1 (AKC57275.1), as a sister group of papaya cytorhabdovirus strains. Furthermore, assuming that the viral surface envelope glycoprotein $G$ interacts directly with receptors 
in the vector cells, a sequence similarity network (EFI-EST webserver) was generated using the glycoprotein amino acid sequences encoded by the 28 cytorhabdoviruses. Interestingly, the analyses show three distinct clusters (aphids, planthopper, and whiteflies) and two singletons (leafhopper and an undescribed vector) with a high degree of interconnectivity.

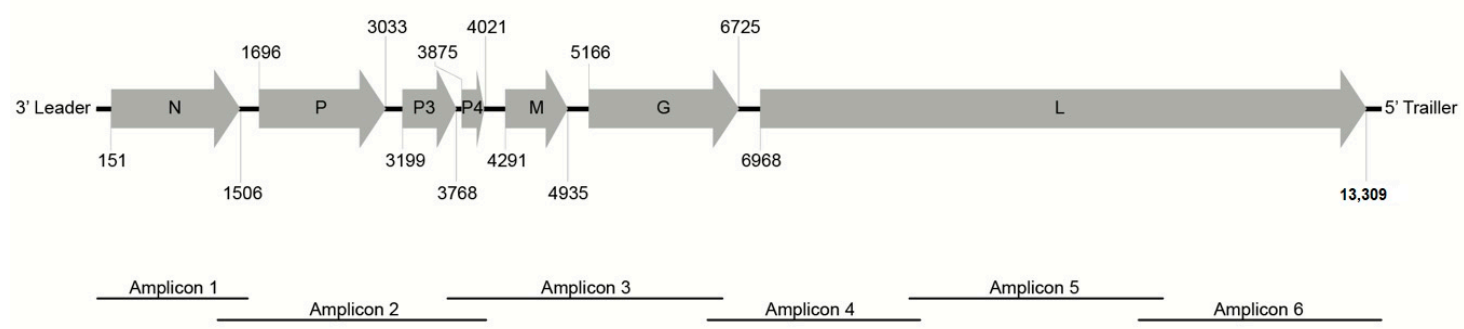

Figure 5. Genome organization of BaCV-Luz. Canonical genes encoding [N] nucleoprotein, [P] phosphoprotein, [M] matrix protein, [G] glycoprotein and [L] RNA-dependent RNA polymerase (RdRp), and non-canonical [P3] and [P4]. Each ORF is represented by a gray arrow with the first and last nucleotide positions depicted. The complete genome (13,467 nts) was recovered by RT-PCR of six overlapping amplicons.
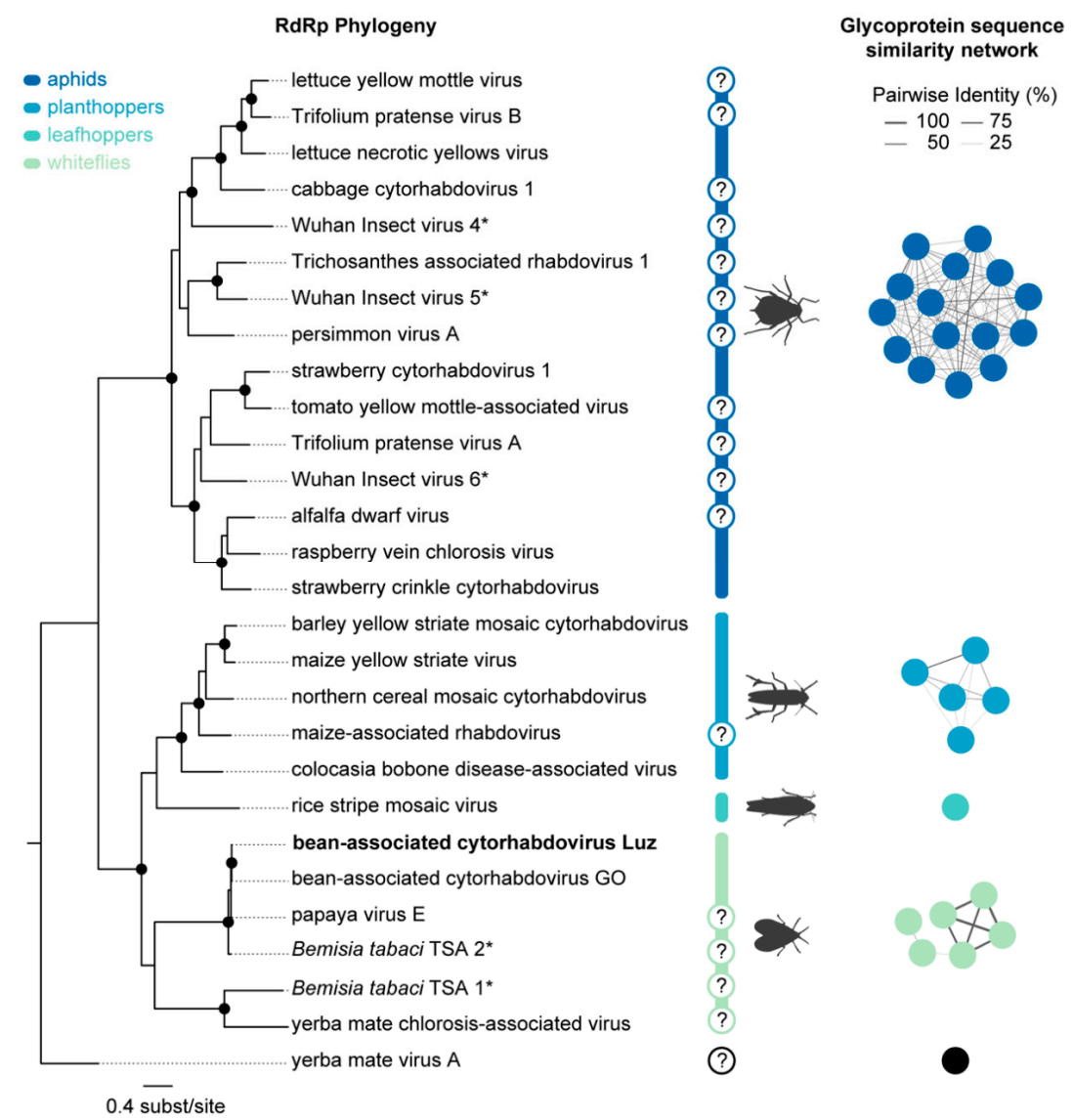

Figure 6. Maximum likelihood phylogenetic tree of cytorhabdovirus RdRP amino acid sequences and sequence similarity network of cytorhabdovirus glycoprotein amino acid sequences encoded by BaCV-Luz, BaCV-GO and other 26 cytorhabdoviruses. In both analyses, four groups were clustered according to their probable vector: aphid, planthopper, leafhopper, and whitefly. Enzyme Function Initiative-Enzyme Similarity Tool (EFI-EST) was used for glycoprotein analysis with an alignment score threshold of 35 and a minimum E-value threshold of $1 \times 10^{-5}$. The network was visualized in Cytoscape v3.7.1. Support values $\geq 90 \% \mathrm{SH}$-aLRT are displayed with black circles at nodes. (?) Unknown vector species. $\left.{ }^{*}\right)$ Viruses detected by insects metatranscriptome. 
These results, together with the detection of BaCV in concomitant infection with the whitefly vectored BGMV and CPMMV in all plants (Figure 4), and with the presence of whiteflies adults, nymphs, and eggs in these plants (Figure 1), prompted us to postulate that whiteflies also vector BaCV.

\subsection{B. tabaci MEAM1 Transmit BaCV-Luz to Common Beans, Cowpea, and Soybean}

The known vectors of cytorhabdoviruses are insects belonging to the families Aphididae (aphids), Delphacidae (planthoppers), and Cicadellidae (leafhoppers). In general, when the vectors are known, there is a highly specific relationship, and only one (or a few related) types or species of a vector are capable of transmitting a given virus. Thus, it is possible to establish a strong correlation between viral detection and the presence of its vector in the field [3,49].

The field in Luziânia, GO, where the bean plants were initially sampled, was densely infested by whiteflies. The genotyping of these whiteflies by PCR-RFLP confirmed their identity as B. tabaci MEAM1, the prevalent whitefly species in Central Brazil [50]. To evaluate whether whiteflies also transmit $\mathrm{BaCV}$, we used a $\mathrm{BaCV}$ (plus BGMV and CPMMV) field-collected infected bean plant as inoculum source and the flies carried by this plant in a free choice transmission assay (Figure 3). After a 14 day exposition time to the whitefly feeding, $100 \%(n=48)$ of the bean plants 'Pérola', 'Jalo', and 'BRS FC 401 RMD' tested positive for the presence of BaCV RNA by RT-PCR. Whitefly adults collected at the same time as bean leaves were also positive for BaCV and CPMMV (Figure S2). All the plants also contained CPMMV, and the susceptible cultivars were positive for BGMV, suggesting that all three viruses were simultaneously transmitted by whiteflies. The mild mottling symptoms detected in 'BRS FC 401 RMD' plants $\sim 50$ days after introduction into the cage (Figure 7) resemble those described for CPMMV infection [51]. These results indicate that BaCV could be transmitted at high rates to three different bean cultivars by whiteflies B. tabaci MEAM1. The BaCV-Luz isolate was maintained by whitefly-mediated periodical transmission to healthy bean plants for 18 months. Altogether, during this period, 83 plants were exposed to potentially viruliferous flies in the cage, and 72 became infected by $\mathrm{BaCV}$, an overall transmission rate of $\sim 87 \%$.

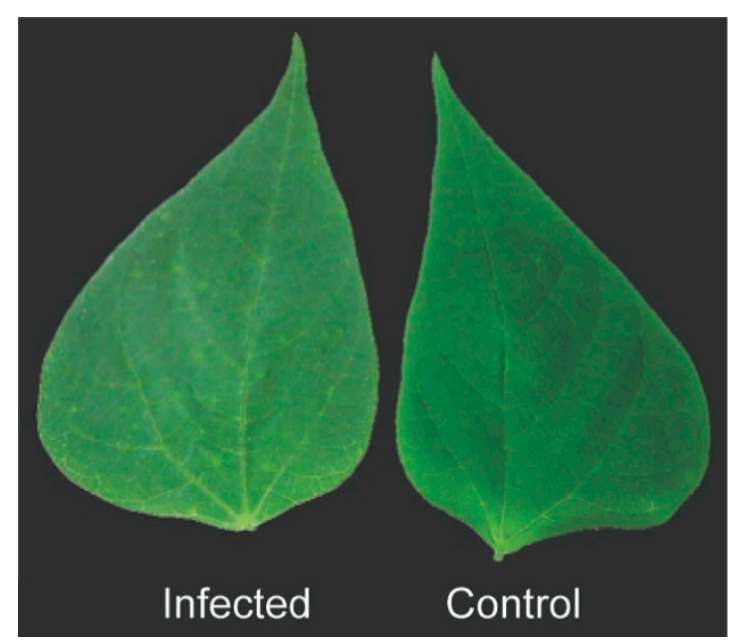

Figure 7. Common bean 'BRS FC 401 RMD' leaves from whitefly mediated BaCV and CPMMV transmission. Mild mottling and chlorotic spots in a leaf of an infected plant at $~ 50$ days after inoculation and the leaf of a non-infected control plant.

A second experiment was conducted to confirm the capacity of whiteflies to transmit $\mathrm{BaCV}$ to common bean as well as soybean and cowpea (Figure 3). Using 25 to 30 adult B. tabaci MEAM1 per plant and both AAP and IAP of 7 days, BaCV transmission was achieved in $75 \%$ of the common beans, $50 \%$ of cowpeas, and $25 \%$ of the soybean plants (Table 2). All control plants exposed to non-viruliferous insects tested negative for $\mathrm{BaCV}$ (and CPMMV). With these results, it was also possible to experimentally extend the host range of $\mathrm{BaCV}$ to cowpea and soybean (Table 2). The second experiment showed a 
transmission efficiency rate lower than the pilot test, in which transmission occurred to $100 \%$ of the plants. The reduction in the efficiency of BaCV transmission may be related to the IAP, which was shorter than in the first experiment. Besides, the number of adult insects feeding on each plant was limited to a maximum of 30, while in the first test, the whiteflies were free to feed so that each plant may have received a larger number of viral particles.

Table 2. BaCV transmission by B. tabaci MEAM1.

\begin{tabular}{cccc}
\hline Plant & Cultivar & Positive/Total & Transmission Rate (\%) \\
\hline P. vulgaris (common bean) & 'BRSFC 401 RMD' & $3 / 4$ & 75 \\
\hline V. unguiculata (cowpea) & 'BRS Imponente' & $2 / 4$ & 50 \\
\hline G. max (soybean) & 'BR16' & $1 / 4$ & 25 \\
\hline
\end{tabular}

Furthermore, the whiteflies' ages were not synchronized in the initial trials, and the insect stage of the life cycle may influence the efficiency of BaCV transmission. Soybean is an economically important cash crop in Brazil and is also susceptible to CPMMV [52] and BGMV [53]. Cultivation cycle of soybean and common bean overlap in many areas of Brazil. In these areas, soybeans may act as an inoculum source of these three whitefly-borne viruses to bean crop hasting multiple virus epidemics. Our future investigation should focus on the study of field infection of soybean plants by BaCV. B. tabaci is a complex containing approximately 40 cryptic species with similar morphology but differing in the genetics, behavior, efficiency as a virus vector, and in the colonization by endosymbionts $[50,54,55]$. B. tabaci has a large number of hosts, more than 500 plant species, cultivated or not, in tropical and subtropical regions. B. tabaci is considered a super vector since it transmits over 300 plant viruses including begomoviruses (family Geminiviridae), criniviruses (family Closteroviridae), torradoviruses (family Secoviridae), ipomoviruses (family Potyviridae), and the carlaviruses CPMMV and melon yellowing-associated virus (MYaV) (family Betaflexiviridae [56,57]). Recently, two poleroviruses (family Luteoviridae) were also shown to be transmitted by B. tabaci [58,59].

Our transmission results demonstrate that whiteflies, in this case the species B. tabaci MEAM1, are vectors of the cytorhabdovirus BaCV in Brazil, highlighting the importance of whiteflies as plant virus vectors and emphasizing their designation as super vectors [56]. Moreover, our results expand the whiteflies' attributes as vectors, including the cytorhabdovirus group, to the list of viruses they can transmit.

Despite whiteflies being successful plant virus vectors, the transmission efficiency may vary depending on the virus, virus isolate, host plant, whitefly species and biology, and virus and whitefly population's geographical origin [57]. In our study, B. tabaci MEAM1 was very efficient in transmitting $\mathrm{BaCV}$, especially to bean plants. B. tabaci MEAM1 predominates as a vector of various plant viruses in Brazil [50]. However, other whitefly species such as B. tabaci Mediterranean (MED) and B. tabaci New World (NW) are also present in more restricted areas of Southeastern and Southern States. Whether whiteflies MED and NW can transmit BaCV to beans or other crops remains to be investigated.

It is also necessary to investigate if $B$. tabaci MEAM1 is the vector of PpVE to papaya plants in Ecuador and if this virus infects papayas in Brazil. Cornejo-Franco, et al. [60] mention that B. tabaci is a major pest of papayas in Ecuador and is the vector of papaya virus $Q$ (an umbra-like virus). Thus, this whitefly species may also be the vector PpVE to papayas. We have tested a limited number of papaya plants $(n=27)$ collected in the Distrito Federal and the State of Espirito Santo for the presence of BaCV with negative results. Nine whitefly species, including B. tabaci MEAM1, were already identified on papaya trees in Brazil, but Trialeurodes variabilis is the primary species associated with this fruit crop, and B. tabaci MEAM1 has a limited occurrence in papayas in the country [61]. Considering that BaCV and PpVE are frequently detected in mixed infections, it is important to investigate if this group of viruses is transmitted alone by B. tabaci MEAM1 or if a helper virus is required. 


\subsection{BaCV-Luz Detection in Plants and Whiteflies}

Depending on the taxonomic group they belong to, viruses are transmitted by their whitefly vectors by different transmission modes [57]. The carlavirus CPMMV is reported to be stylet borne and transmitted in a nonpersistent mode [52]. While criniviruses, torradoviruses, and ipomoviruses are semipersistent viruses and foregut borne, the mode of transmission of poleroviruses by $B$. tabaci is still unknown [56,57]. Begomoviruses are transmitted by different species in the $B$. tabaci complex in a persistent circulative manner. However, at least for one begomovirus, tomato yellow leaf curl virus (TYLCV), there is evidence that it replicates in the whitefly [62-65] and that replication takes place mainly in the salivary glands [66].

Plant rhabdoviruses are transmitted by their arthropod vectors in a persistent, circulative-propagative manner. After the acquisition, viruliferous insects transmit plant rhabdoviruses for their entire lives. In plants, rhabdoviruses infect, replicate, and accumulate in a variety of tissues, including leaf epidermis and mesophyll, phloem tissues, and roots [5,67]. In their insect vectors, plant rhabdoviruses infect gut cells, muscle cells, nervous tissue, hemocytes, tracheae, and salivary glands $[3,5,28]$.

BaCV RNA corresponding to N, P, P3, P4, M, G genes were amplified from BaCV-infected bean leaves and potentially viruliferous whiteflies collected in infected plants. Fragments with sizes according to their predicted ORFs were amplified (Figure 8a,b), except for L, probably because of its large size. Amplicons corresponding to $a c t 11$ and $R b c S$ were only amplified from bean cDNA, and $v$-ATPase and RpL9 from whiteflies (Figure $8 \mathrm{a}, \mathrm{b}$ ).

(a)

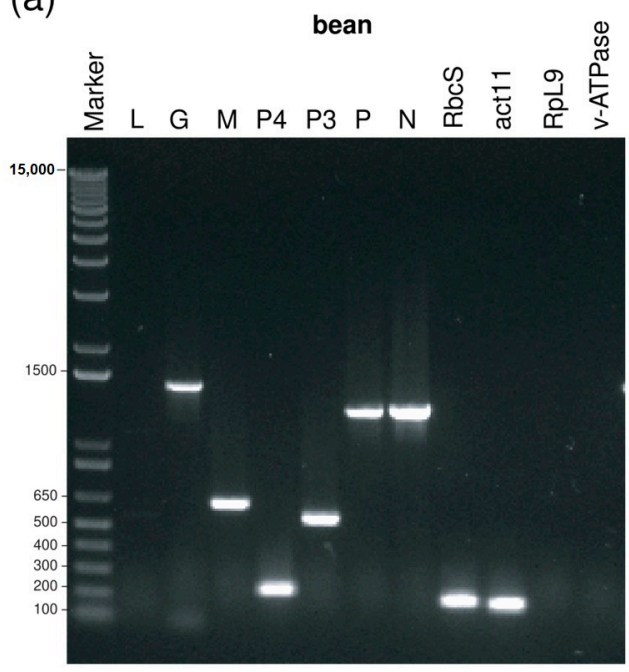

(b)

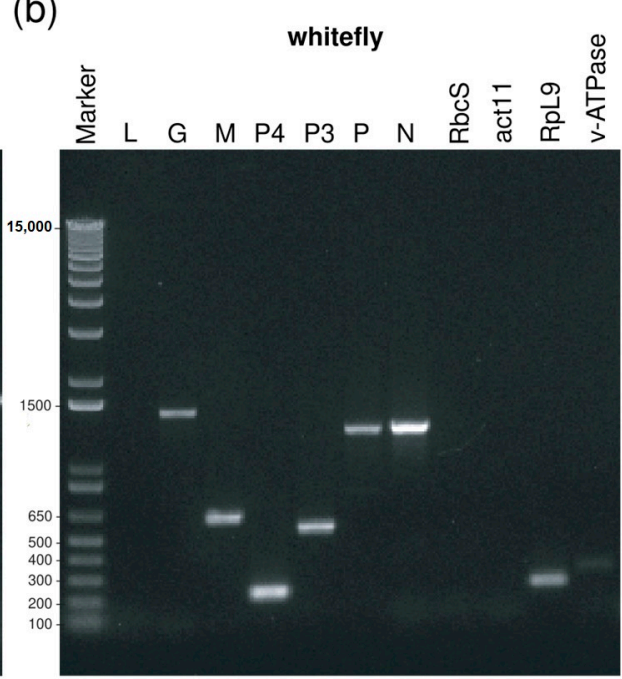

Figure 8. BaCV detection in common bean leaf and whiteflies (B. tabaci MEAM1). BaCV RNA corresponding to G, M, P4, P3, P, N genes were detected by PCR using specific primers. Internal controls include the plant $R b c S$ and $a c t 11$ and the whitefly RpL9 and $v$-ATPase. (a) RT-PCR products obtained from RNA extracted from common bean. (b) RT-PCR products obtained from RNA extracted from viruliferous whiteflies.

We have used transmission electron microscopy (TEM) to visualize BaCV accumulation in bean and whitefly tissues. Electron microscopic examination of BaCV-infected bean leaves revealed bacilliform particles typical of rhabdoviruses in parenchymal cells. Longitudinal and cross-sectioned particles were located in the cell cytoplasm, commonly at the periphery of an electron-lucent mass of coiled filamentous material, believed to be the viroplasm, where the virus replicates (Figure 9a-d) [5,68]. The BaCV bacilliform particles seemed rather scarce in the observed bean tissues. Presumed cytorhabdovirus virions were found in only one of the four examined leaf samples, though all plant samples tested positive for BaCV by RT-PCR. 

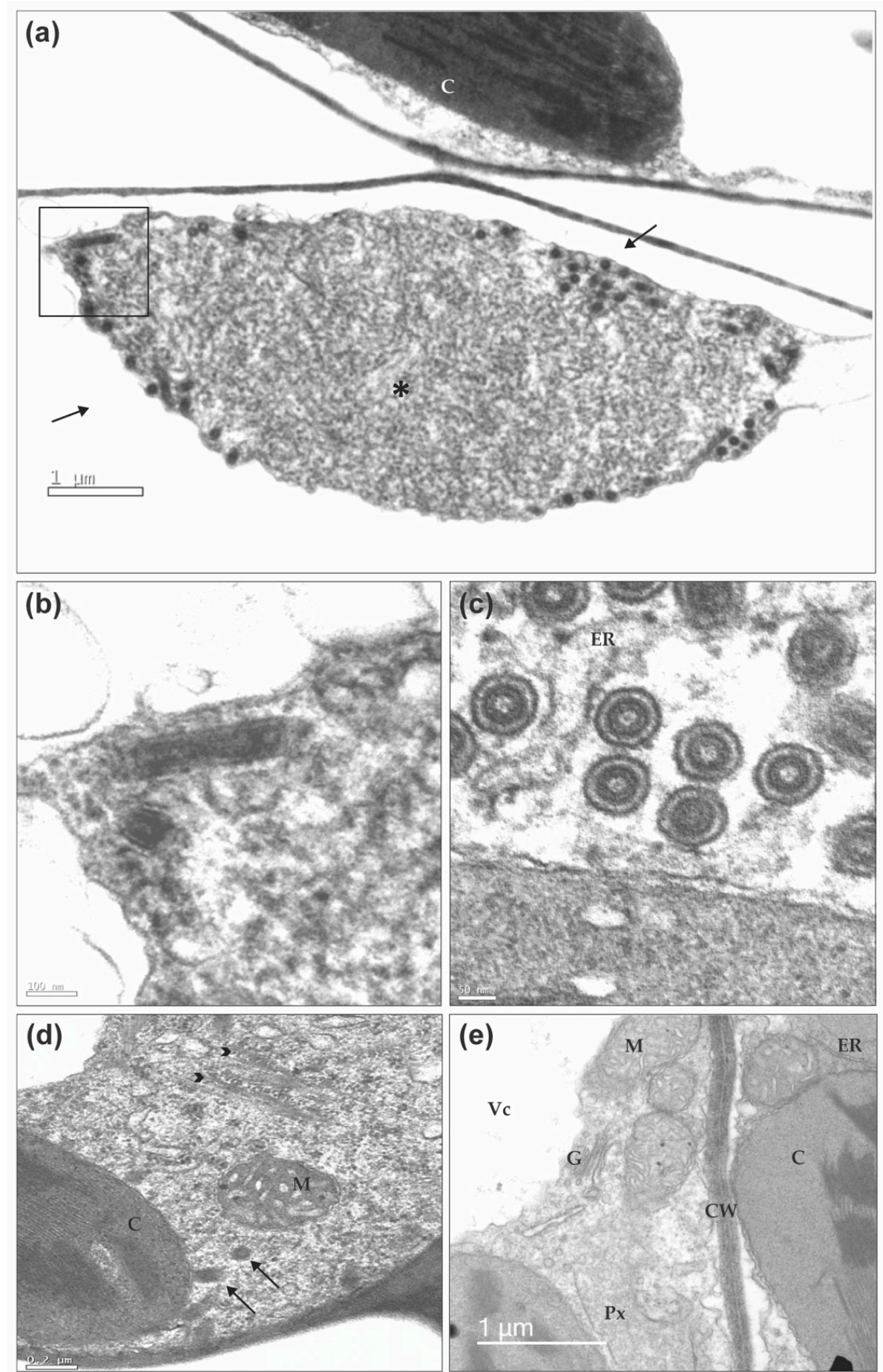

Figure 9. Transmission electron micrographs of bean leaf infected by BaCV. (a) Overview of a viroplasm formed by coiled filamentous material $\left(^{*}\right)$ in the cytoplasm of a parenchymal cell. Typical rhabdovirus particles are present in the periphery of the viroplasm (arrows). (b) Details of the marked square with longitudinally-sectioned particles are depicted. (c) Cross-sections of BaCV particles show the internal and cylindrical nucleoprotein core, and the outer viral membrane, and also that virions are within a cavity of the endoplasmic reticulum. (d) Spongy parenchymal cell dually infected by BaCV and CPMMV. Brush-like aggregates of CPMMV particles (arrowheads) and BaCV in longitudinal and cross-sections (arrows) are visible. (e) Palisade parenchyma cells from a healthy bean plant. Chloroplast $(\mathrm{C})$, endoplasmic reticulum (ER), Golgi complex (G), mitochondrion (M), peroxisome (Px), vacuole $(\mathrm{Vc})$, and cell wall $(\mathrm{CW})$. 
By contrast, feather-like aggregates of CPMMV particles were readily recognized in all examined bean tissue samples. These in situ observations of $\mathrm{BaCV}$ and CPMMV virions presence in dually infected bean leaf corroborate the previous HTS sequencing study in which $8.2 \%$ of the total sequence reads from multiple virus-infected bean leaves corresponded to CPMMV whereas only $0.01 \%$ mapped to $\mathrm{BaCV}$ [6]. In some cases, BaCV and CPMMV virions could be identified infecting the same cell (Figure 9d). Unfortunately, sections of three pairs of head/thorax or abdominal parts of whiteflies that fed in BaCV-infected beans did not yield evidence of $\mathrm{BaCV}$ particles or viroplasm in the observed tissues. The insects were tested before fixation, and only head/thorax corresponding to insects that the abdomen tested positive for BaCV or vice-versa was examined. Therefore, albeit BaCV RNA could be detected in the insects by RT-PCR, particles were not localized in any of the tissues examined.

The spatial and temporal distribution of $\mathrm{BaCV}$ within the whitefly body could have hindered the localization of particles by TEM. Moreover, plant rhabdoviruses appear to replicate and accumulate at lower levels in insect cells when compared to plant cells $[3,6,69]$. BaCV seems to accumulate at low levels, even in bean plants. Therefore, assessment of dissected organs such as midguts or salivary glands could facilitate the visualization of $\mathrm{BaCV}$ in whiteflies either by TEM or by confocal microscopy using immunofluorescence or in situ hybridization. The occurrence of BaCV vRNA, cRNA, and mRNA in whiteflies will be investigated in future studies.

\section{Conclusions}

Our results show that $\mathrm{BaCV}$ is efficiently transmitted, in experimental conditions, by $B$. tabaci MEAM1 to three bean cultivars grown in Brazil, and with lower efficiency to cowpea and soybean. It remains to be determined whether $\mathrm{BaCV}$ replicates in whiteflies, as observed for other plant-infecting rhabdoviruses in their arthropod vectors. BaCV could not be singly isolated for pathogenicity tests, identification of the induced symptoms, and the transmission assay. Moreover, $\mathrm{BaCV}$ was detected in five out of seven Brazilian states evaluated. Besides BaCV in Brazil (this study, [6]) and PpVE in Ecuador [7], similar virus sequences were recorded from whiteflies samples in India [70], beans from Tanzania [71], and citrus, passion fruit, and paper bush in China [72], implying that other isolates/strains of $\mathrm{BaCV} / \mathrm{PpVE}$ or related rhabdoviruses that are also transmitted by whiteflies might exist in other continents.

Supplementary Materials: The following are available online at http:/www.mdpi.com/1999-4915/12/9/1028/s1, Figure S1: RT-PCR and PCR detection of bean-infecting viruses, Figure S2: RT-PCR detection of BaCV and CPMMV, Table S1: Primers used in this study, Table S2: Accession number of cytorhabdoviruses sequences in GenBank and their known vectors, Table S3: Nucleotide and amino acid sequence identities (\%) of BaCV-Luz ORFs compared with PpEV strains.

Author Contributions: Conceptualization, B.P.-L., R.C.P.-C., S.G.R. and F.L.M.; Data curation, B.P.-L. and F.L.M.; Formal analysis, B.P.-L., R.S.F. and F.L.M.; Funding acquisition, A.V., S.G.R. and F.L.M.; Investigation, B.P.-L., D.M.T.A.-F., E.W.K., A.H.V., M.T.G. and R.S.F.; Methodology, B.P.-L., E.W.K. and F.L.M.; Project administration, J.C.F., S.G.R. and F.L.M.; Resources, J.C.F., E.F.M.A., S.G.R. and F.L.M.; Supervision, R.C.P.-C., S.G.R. and F.L.M.; Visualization, B.P.-L., C.L. and F.L.M.; Writing-original draft, B.P.-L., S.G.R. and F.L.M.; Writing-review \& editing, B.P.-L., R.C.P.-C., D.M.T.A.-F., E.W.K., A.H.V., C.L., R.S.F., J.C.F., A.V., S.G.R. and F.L.M. All authors have read and agreed to the published version of the manuscript.

Funding: This research was funded by grants from Embrapa, Conselho Nacional de Desenvolvimento Científico e Tecnológico-CNPq and Fundação de Apoio à Pesquisa do Distrito Federal-FAP/DF. B.P.-L. and A.H.V. are supported by scholarships from Coordenação de Aperfeiçoamento de Pessoal de Nível Superior-CAPES. D.M.T.A.-F. and M.T.G. received fellowships from CNPq.

Acknowledgments: We thank Rafael N. Lemos, Rodrigo Carniel, Luis C. Faria, Mônica Neli, and Marlonni Marastoni for helping in sample collection or sharing plant material; Mário Saraiva for technical support and assistance in the lab administration.

Conflicts of Interest: The authors declare no conflict of interest. The funders, including Embrapa, had no role in the design of the study; in the collection, analyses, or interpretation of data; in the writing of the manuscript, or in the decision to publish the results. 


\section{References}

1. Freitas-Astua, J.; Dietzgen, R.G.; Walker, P.J.; Blasdell, K.R.; Breyta, R.; Fooks, A.R.; Kondo, H.; Kurath, G.; Kuzmin, I.V.; Stone, D.M.; et al. Split the genus Nucleorhabdovirus, creating three new genera (Alphanucleorhabdovirus, Betanucleorhabdovirus and Gammanucleorhabdovirus) comprising sixteen species, including six new species, in the family Rhabdoviridae. Approved ICTV Proposal. 2019. Available online: https://ictv.global/ICTV/proposals/2019.031M.zip (accessed on 18 May 2020).

2. Walker, P.J.; Blasdell, K.R.; Calisher, C.H.; Dietzgen, R.G.; Kondo, H.; Kurath, G.; Longdon, B.; Stone, D.M.; Tesh, R.B.; Tordo, N.; et al. ICTV Virus Taxonomy Profile: Rhabdoviridae. J. Gen. Virol. 2018, 99, 447-448. [CrossRef]

3. Ammar, E.D.; Tsai, C.W.; Whitfield, A.E.; Redinbaugh, M.G.; Hogenhout, S.A. Cellular and molecular aspects of rhabdovirus interactions with insect and plant hosts. Annu. Rev. Entomol. 2009, 54, 447-468. [CrossRef] [PubMed]

4. Dietzgen, R.G.; Kondo, H.; Goodin, M.M.; Kurath, G.; Vasilakis, N. The family Rhabdoviridae: Mono- and bipartite negative-sense RNA viruses with diverse genome organization and common evolutionary origins. Virus Res. 2017, 227, 158-170. [CrossRef]

5. Whitfield, A.E.; Huot, O.B.; Martin, K.M.; Kondo, H.; Dietzgen, R.G. Plant rhabdoviruses-their origins and vector interactions. Curr. Opin. Virol. 2018, 33, 198-207. [CrossRef]

6. Alves-Freitas, D.M.T.; Pinheiro-Lima, B.; Faria, J.C.; Lacorte, C.; Ribeiro, S.G.; Melo, F.L. Double-Stranded RNA High-Throughput Sequencing Reveals a New Cytorhabdovirus in a Bean Golden Mosaic Virus-Resistant Common Bean Transgenic Line. Viruses 2019, 11, 90. [CrossRef]

7. Medina-Salguero, A.X.; Cornejo-Franco, J.F.; Grinstead, S.; Mollov, D.; Mowery, J.D.; Flores, F.; Quito-Avila, D.F. Sequencing, genome analysis and prevalence of a cytorhabdovirus discovered in Carica papaya. PLoS ONE 2019, 14, e0215798. [CrossRef]

8. Freitas-Astua, J.; Dietzgen, R.G.; Walker, P.J.; Blasdell, K.R.; Breyta, R.; Fooks, A.R.; Kondo, H.; Kurath, G.; Kuzmin, I.V.; Stone, D.M.; et al. Create twelve new species in the genus Cytorhabdovirus, family Rhabdoviridae. Approved ICTV Proposal. 2019. Available online: https://ictv.global/ICTV/proposals/ 2019.030M.zip (accessed on 18 May 2020).

9. International Committee on Taxonomy of Viruses-ICTV Online. Available online: https://talk.ictvonline. org/ictv-reports/ictv_online_report/negative-sense-rna-viruses/mononegavirales/w/rhabdoviridae (accessed on 18 May 2020).

10. Instituto Brasileiro de Geografia e Estatística-IBGE. Available online: https://www.ibge.gov.br (accessed on 24 July 2020).

11. Doyle, J.J.; Doyle, J.L. A rapid DNA isolation procedure for small quantities of fresh leaf tissue. Phytochem. Bull. 1987, 19, 11-15.

12. Nicolini, C.; Pio-Ribeiro, G.; Andrade, G.P.; Melo, F.L.; Oliveira, V.C.; Guimaraes, F.C.; Resende, R.O.; Kitajima, E.W.; Rezende, J.A.; Nagata, T. A distinct tymovirus infecting Cassia hoffmannseggii in Brazil. Virus Genes 2012, 45, 190-194. [CrossRef]

13. Schuster, D.; Buchman, G.; Rashtchian, A. A simple and efficient method for amplification of cDNA ends using 5' RACE. Focus 1992, 14, 46-52.

14. Pinheiro-Lima, B.; Alves-Freitas, D.M.T.; Melo, F.L.; Carvalho, R.; de Faria, J.C.; Ribeiro, S.G. Characterization of a new whitefly-transmitted (Bemisia tabaci MEAM 1) cytorhabdovirus infecting common bean. Congr. Nac. Pesqui. Feijão 2017, 12, 52.

15. Lamas, N.S.; Matos, V.O.R.L.; Alves-Freitas, D.M.T.; Melo, F.L.; Costa, A.F.; Faria, J.C.; Ribeiro, S.G. Occurrence of Cowpea mild mottle virus in Common Bean and Associated Weeds in Northeastern Brazil. Plant Dis. 2017, 101, 1828. [CrossRef]

16. Bonfim, K.; Faria, J.C.; Nogueira, E.O.; Mendes, E.A.; Aragao, F.J. RNAi-mediated resistance to Bean golden mosaic virus in genetically engineered common bean (Phaseolus vulgaris). Mol. Plant Microbe Interact 2007, 20, 717-726. [CrossRef] [PubMed]

17. Bosco, D.; Loria, A.; Sartor, C.; Cenis, J. PCR-RFLP Identification of Bemisia tabaci biotypes in the Mediterranean Basin. Phytoparasitica 2006, 34, 243-251. [CrossRef] 
18. Kearse, M.; Moir, R.; Wilson, A.; Stones-Havas, S.; Cheung, M.; Sturrock, S.; Buxton, S.; Cooper, A.; Markowitz, S.; Duran, C.; et al. Geneious Basic: An integrated and extendable desktop software platform for the organization and analysis of sequence data. Bioinformatics 2012, 28, 1647-1649. [CrossRef]

19. Altschul, S.F.; Gish, W.; Miller, W.; Myers, E.W.; Lipman, D.J. Basic local alignment search tool. J. Mol. Biol. 1990, 215, 403-410. [CrossRef]

20. Katoh, K.; Rozewicki, J.; Yamada, K.D. MAFFT online service: Multiple sequence alignment, interactive sequence choice and visualization. Brief. Bioinform. 2019, 20, 1160-1166. [CrossRef]

21. Trifinopoulos, J.; Nguyen, L.T.; von Haeseler, A.; Minh, B.Q. W-IQ-TREE: A fast online phylogenetic tool for maximum likelihood analysis. Nucleic Acids Res. 2016, 44, W232-W235. [CrossRef]

22. Shimodaira, H. An approximately unbiased test of phylogenetic tree selection. Syst. Biol. 2002, 51, 492-508. [CrossRef]

23. Gerlt, J.A.; Bouvier, J.T.; Davidson, D.B.; Imker, H.J.; Sadkhin, B.; Slater, D.R.; Whalen, K.L. Enzyme Function Initiative-Enzyme Similarity Tool (EFI-EST): A web tool for generating protein sequence similarity networks. Biochim. Biophys. Acta 2015, 1854, 1019-1037. [CrossRef]

24. Shannon, P.; Markiel, A.; Ozier, O.; Baliga, N.S.; Wang, J.T.; Ramage, D.; Amin, N.; Schwikowski, B.; Ideker, T. Cytoscape: A software environment for integrated models of biomolecular interaction networks. Genome Res. 2003, 13, 2498-2504. [CrossRef]

25. Muhire, B.M.; Varsani, A.; Martin, D.P. SDT: A virus classification tool based on pairwise sequence alignment and identity calculation. PLoS ONE 2014, 9, e108277. [CrossRef] [PubMed]

26. Faria, J.C.; Aragão, F.J.L.; Souza, T.L.P.O.; Quintela, E.D.; Kitajima, E.W.; Ribeiro, S.G. Golden mosaic of common beans in Brazil: Management with a transgenic approach. APS Features 2016, 10, 1-14.

27. Orfanidou, C.G.; Pappi, P.G.; Efthimiou, K.E.; Katis, N.I.; Maliogka, V.I. Transmission of Tomato chlorosis virus (ToCV) by Bemisia tabaci Biotype $Q$ and Evaluation of Four Weed Species as Viral Sources. Plant Dis. 2016, 100, 2043-2049. [CrossRef] [PubMed]

28. Cao, Q.; Xu, W.Y.; Gao, Q.; Jiang, Z.H.; Liu, S.Y.; Fang, X.D.; Gao, D.M.; Wang, Y.; Wang, X.B. Transmission Characteristics of Barley Yellow Striate Mosaic Virus in Its Planthopper Vector Laodelphax striatellus. Front. Microbiol. 2018, 9, 1419. [CrossRef]

29. Borges, A.; Tsai, S.M.; Caldas, D.G. Validation of reference genes for RT-qPCR normalization in common bean during biotic and abiotic stresses. Plant Cell Rep. 2012, 31, 827-838. [CrossRef]

30. Knight, M.R.; Jenkins, G.I. Genes encoding the small subunit of ribulose 1,5-bisphosphate carboxylase/oxygenase in Phaseolus vulgaris L.: Nucleotide sequence of cDNA clones and initial studies of expression. Plant Mol. Biol. 1992, 18, 567-579. [CrossRef] [PubMed]

31. Upadhyay, S.K.; Chandrashekar, K.; Thakur, N.; Verma, P.C.; Borgio, J.F.; Singh, P.K.; Tuli, R. RNA interference for the control of whiteflies (Bemisia tabaci) by oral route. J. Biosci. 2011, 36, 153-161. [CrossRef] [PubMed]

32. Alves-Freitas, D.M.T.; Melo, F.L.; Faria, J.C.; Ribeiro, S.G. dsRNA deep sequencing reveals five viral species in common beans. J. Braz. Soc. Virol. 2016, 20, 43-44.

33. Moreno, A.B.; Lopez-Moya, J.J. When Viruses Play Team Sports: Mixed Infections in Plants. Phytopathology 2020, 110, 29-48. [CrossRef] [PubMed]

34. Gautam, S.; Gadhave, K.R.; Buck, J.W.; Dutta, B.; Coolong, T.; Adkins, S.; Srinivasan, R. Virus-virus interactions in a plant host and in a hemipteran vector: Implications for vector fitness and virus epidemics. Virus Res. 2020, 286, 198069. [CrossRef] [PubMed]

35. Francki, R.I.B.; Randles, J.W.; Dietzgen, R.G. Lettuce necrotic yellows virus. AAB Descr. Plant Viruses 1989, 343,5 .

36. Jones, S.; McGavin, W.; MacFarlane, S. The complete sequences of two divergent variants of the rhabdovirus raspberry vein chlorosis virus and the design of improved primers for virus detection. Virus Res. 2019, 265, 162-165. [CrossRef]

37. Sylvester, E.S.; Richardson, J.; Frazier, N.W. Serial passage of strawberry crinkle virus in the aphid Chaetosiphon jacobi. Virology 1974, 59, 301-306. [CrossRef]

38. Franova, J.; Pribylova, J.; Koloniuk, I. Molecular and Biological Characterization of a New Strawberry Cytorhabdovirus. Viruses 2019, 11, 982. [CrossRef]

39. Li, C.X.; Shi, M.; Tian, J.H.; Lin, X.D.; Kang, Y.J.; Chen, L.J.; Qin, X.C.; Xu, J.; Holmes, E.C.; Zhang, Y.Z. Unprecedented genomic diversity of RNA viruses in arthropods reveals the ancestry of negative-sense RNA viruses. eLife 2015, 4. [CrossRef] [PubMed] 
40. Conti, M.; Appiano, A. Barley yellow striate mosaic virus and associated viroplasms in barley cells. J. Gen. Virol. 1973, 21, 315-322. [CrossRef]

41. Gollifer, D.E.; Jackson, G.V.H.; Dabek, A.J.; Plumb, R.T.; May, Y.Y. The occurrence and transmission of viruses of edible aroids in the Solomon Islands and the Southwest Pacific. Pestic. Artic. News Summ. 1977, 23, 171-177. [CrossRef]

42. Maurino, M.F.; Laguna, G.; Giolitti, F.; Nome, C.; Pecci, M.P.G. First Ocurrence of a Rhabdovirus Infecting Maize in Argentina. Plant Dis. 2012, 96, 1383. [CrossRef] [PubMed]

43. Maurino, F.; Dumon, A.D.; Llauger, G.; Alemandri, V.; de Haro, L.A.; Mattio, M.F.; Del Vas, M.; Laguna, I.G.; Gimenez Pecci, M.P. Complete genome sequence of maize yellow striate virus, a new cytorhabdovirus infecting maize and wheat crops in Argentina. Arch. Virol. 2018, 163, 291-295. [CrossRef] [PubMed]

44. Toriyama, S. Purification and some properties of northern cereal mosaic virus. Uirusu 1972, 22, 114-124. [CrossRef]

45. Toriyama, S. Northern cereal mosaic. In Viruses and Virus Diseases of Poaceae (Gramineae); Lapierre, H., Signoret, P.-A., Eds.; INRA: Paris, France, 2004; pp. 578-580.

46. Yang, X.; Huang, J.; Liu, C.; Chen, B.; Zhang, T.; Zhou, G. Rice Stripe Mosaic Virus, a Novel Cytorhabdovirus Infecting Rice via Leafhopper Transmission. Front. Microbiol. 2016, 7, 2140. [CrossRef] [PubMed]

47. Bejerman, N.; Dietzgen, R.G. Letter to the Editor: Bean-Associated Cytorhabdovirus and Papaya Cytorhabdovirus are Strains of the Same Virus. Viruses 2019, 11, 230. [CrossRef] [PubMed]

48. Dietzgen, R.G.; Bejerman, N.E.; Goodin, M.M.; Higgins, C.M.; Huot, O.B.; Kondo, H.; Martin, K.M.; Whitfield, A.E. Diversity and epidemiology of plant rhabdoviruses. Virus Res. 2020, 281, 197942. [CrossRef] [PubMed]

49. Mann, K.S.; Dietzgen, R.G. Plant rhabdoviruses: New insights and research needs in the interplay of negative-strand RNA viruses with plant and insect hosts. Arch. Virol. 2014, 159, 1889-1900. [CrossRef]

50. de Moraes, L.A.; Muller, C.; Bueno, R.; Santos, A.; Bello, V.H.; De Marchi, B.R.; Watanabe, L.F.M.; Marubayashi, J.M.; Santos, B.R.; Yuki, V.A.; et al. Distribution and phylogenetics of whiteflies and their endosymbiont relationships after the Mediterranean species invasion in Brazil. Sci. Rep. 2018, 8, 14589. [CrossRef]

51. Carvalho, S.L.; Nagata, T.; Junqueira, B.R.; Zanardo, L.G.; Paiva, A.C.; Carvalho, C.M. Construction of a full-length infectious cDNA clone of Cowpea mild mottle virus. Virus Genes 2017, 53, 137-140. [CrossRef]

52. Zanardo, L.G.; Carvalho, C.M. Cowpea mild mottle virus (Carlavirus, Betaflexiviridae): A review. Trop. Plant Pathol. 2017, 42, 417-430. [CrossRef]

53. Fernandes, F.R.; Cruz, A.R.; Faria, J.C.; Zerbini, F.M.; Aragao, F.J. Three distinct begomoviruses associated with soybean in central Brazil. Arch. Virol. 2009, 154, 1567-1570. [CrossRef]

54. De Barro, P.J.; Liu, S.S.; Boykin, L.M.; Dinsdale, A.B. Bemisia tabaci: A statement of species status. Annu. Rev. Entomol. 2011, 56, 1-19. [CrossRef]

55. Lee, W.; Park, J.; Lee, G.S.; Lee, S.; Akimoto, S. Taxonomic status of the Bemisia tabaci complex (Hemiptera: Aleyrodidae) and reassessment of the number of its constituent species. PLoS ONE 2013, 8, e63817. [CrossRef]

56. Gilbertson, R.L.; Batuman, O.; Webster, C.G.; Adkins, S. Role of the Insect Supervectors Bemisia tabaci and Frankliniella occidentalis in the Emergence and Global Spread of Plant Viruses. Annu. Rev. Virol. 2015, 2, 67-93. [CrossRef] [PubMed]

57. Fiallo-Olive, E.; Pan, L.L.; Liu, S.S.; Navas-Castillo, J. Transmission of Begomoviruses and Other Whitefly-Borne Viruses: Dependence on the Vector Species. Phytopathology 2020, 110, 10-17. [CrossRef] [PubMed]

58. Ghosh, S.; Kanakala, S.; Lebedev, G.; Kontsedalov, S.; Silverman, D.; Alon, T.; Mor, N.; Sela, N.; Luria, N.; Dombrovsky, A.; et al. Transmission of a New Polerovirus Infecting Pepper by the Whitefly Bemisia tabaci. J. Virol. 2019, 93. [CrossRef] [PubMed]

59. Costa, T.M.; Inoue-Nagata, A.K.; Vidal, A.H.; Ribeiro, S.G.; Nagata, T. The recombinant isolate of cucurbit aphid-borne yellows virus from Brazil is a polerovirus transmitted by whiteflies. Plant Pathol. 2020, 69, 1042-1050. [CrossRef]

60. Cornejo-Franco, J.F.; Alvarez-Quinto, R.A.; Quito-Avila, D.F. Transmission of the umbra-like Papaya virus $\mathrm{Q}$ in Ecuador and its association with meleira-related viruses from Brazil. Crop Prot. 2018, 110, 99-102. [CrossRef] 
61. Martins, D.S.; Lima, A.F.; Fornazier, M.J.; Barcellos, B.D.; Queiroz, R.B.; Fanton, C.J.; Zanuncio-Junior, J.S.; Fornazier, D.L. Whiteflies (Hemiptera: Aleyrodidae) Associated with papaya (Carica papaya L.). Rev. Científica Intelletto 2016, 2, 78-86.

62. Sinisterra, X.H.; McKenzie, C.L.; Hunter, W.B.; Powell, C.A.; Shatters, R.G. Differential transcriptional activity of plant-pathogenic begomoviruses in their whitefly vector (Bemisia tabaci, Gennadius: Hemiptera Aleyrodidae). J. Gen. Virol. 2005, 86, 1525-1532. [CrossRef]

63. Pakkianathan, B.C.; Kontsedalov, S.; Lebedev, G.; Mahadav, A.; Zeidan, M.; Czosnek, H.; Ghanim, M. Replication of Tomato Yellow Leaf Curl Virus in Its Whitefly Vector, Bemisia tabaci. J. Virol. 2015, 89, 9791-9803. [CrossRef]

64. Wang, L.L.; Wang, X.R.; Wei, X.M.; Huang, H.; Wu, J.X.; Chen, X.X.; Liu, S.S.; Wang, X.W. The autophagy pathway participates in resistance to tomato yellow leaf curl virus infection in whiteflies. Autophagy 2016, 12, 1560-1574. [CrossRef]

65. Czosnek, H.; Ghanim, M.; Morin, S.; Rubinstein, G.; Fridman, V.; Zeidan, M. Whiteflies: Vectors, and victims (?), of geminiviruses. Adv. Virus Res. 2001, 57, 291-322. [CrossRef]

66. He, Y.Z.; Wang, Y.M.; Yin, T.Y.; Fiallo-Olive, E.; Liu, Y.Q.; Hanley-Bowdoin, L.; Wang, X.W. A plant DNA virus replicates in the salivary glands of its insect vector via recruitment of host DNA synthesis machinery. Proc. Natl. Acad. Sci. USA 2020, 117, 16928-16937. [CrossRef]

67. Jackson, A.O.; Dietzgen, R.G.; Goodin, M.M.; Bragg, J.N.; Deng, M. Biology of plant rhabdoviruses. Annu. Rev. Phytopathol. 2005, 43, 623-660. [CrossRef] [PubMed]

68. Jackson, A.O.; Dietzgen, R.G.; Goodin, M.M.; Li, Z. Development of Model Systems for Plant Rhabdovirus Research. Adv. Virus Res. 2018, 102, 23-57. [CrossRef] [PubMed]

69. Ammar, E.D.; Hogenhout, S.A. A neurotropic route for Maize mosaic virus (Rhabdoviridae) in its planthopper vector Peregrinus maidis. Virus Res. 2008, 131, 77-85. [CrossRef]

70. Upadhyay, S.K.; Sharma, S.; Singh, H.; Dixit, S.; Kumar, J.; Verma, P.C.; Chandrashekar, K. Whitefly genome expression reveals host-symbiont interaction in amino acid biosynthesis. PLoS ONE 2015, 10, e0126751. [CrossRef]

71. Mwaipopo, B.; Nchimbi-Msolla, S.; Njau, P.J.R.; Mark, D.; Mbanzibwa, D.R. Comprehensive Surveys of Bean common mosaic virus and Bean common mosaic necrosis virus and Molecular Evidence for Occurrence of Other Phaseolus vulgaris Viruses in Tanzania. Plant Dis. 2018, 102, 2361-2370. [CrossRef] [PubMed]

72. Zhang, S.; Huang, A.; Zhou, X.; Li, Z.; Dietzgen, R.G.; Zhou, C.Y.; Cao, M. Natural defect of a plant rhabdovirus glycoprotein gene: A case study of virus-plant co-evolution. Phytopathology 2020. [CrossRef] 